\title{
Continuous atmospheric boundary layer observations in the coastal urban area of Barcelona during SAPUSS
}

\author{
M. Pandolfi ${ }^{1}$, G. Martucci ${ }^{2}$, X. Querol ${ }^{1}$, A. Alastuey ${ }^{1}$, F. Wilsenack ${ }^{3}$, S. Frey ${ }^{4}$, C. D. O'Dowd ${ }^{2}$, and M. Dall'Osto ${ }^{1}$ \\ ${ }^{1}$ Institute of Environmental Assessment and Water Research (IDAEA-CSIC), Barcelona, Spain \\ ${ }^{2}$ School of Physics \& Centre for Climate and Air Pollution Studies, Ryan Institute, National University of Ireland Galway, \\ University Road, Galway, Ireland \\ ${ }^{3}$ Wehrwissenschaftliches Institut für Schutztechnologien - ABC-Schutz, Munster, Germany \\ ${ }^{4}$ Jenoptik Laser, Optik, Systeme GmbH, Jena, Germany
}

Correspondence to: M. Pandolfi (marco.pandolfi@idaea.csic.es)

Received: 19 December 2012 - Published in Atmos. Chem. Phys. Discuss.: 7 January 2013

Revised: 17 April 2013 - Accepted: 18 April 2013 - Published: 14 May 2013

\begin{abstract}
Continuous measurements of surface mixed layer (SML), decoupled residual/convective layer (DRCL) and aerosol backscatter coefficient were performed within the Barcelona (Spain) boundary layer from September to October 2010 (30 days) in the framework of the SAPUSS (Solving Aerosol Problems by Using Synergistic Strategies) field campaign. Two near-infrared ceilometers (Jenoptik CHM15K), vertically and horizontally probing (only vertical profiles are herein discussed), were deployed. Ceilometer-based DRCLs (1761 $\pm 363 \mathrm{~m}$ a.g.1.) averaged over the campaign duration were twice as high as the mean SML (904 $\pm 273 \mathrm{~m}$ a.g.1.). Both DRCL and SML showed a marked SML diurnal cycle. Ceilometer data were compared with potential temperature profiles measured by daily radiosounding (twice a day, midnight and midday) to interpret the boundary layer structure in the coastal urban area of Barcelona. The overall agreement $\left(R^{2}=0.80\right)$ between the ceilometer-retrieved and radiosounding-based SML heights $(h)$ revealed overestimation of the SML by the ceilometer $(\Delta h=145 \pm 145 \mathrm{~m})$. After separating the data in accordance with different atmospheric scenarios, the lowest SML $(736 \pm 183 \mathrm{~m})$ and DRCL $(1573 \pm 428 \mathrm{~m})$ were recorded during warm North African (NAF) advected air mass. By contrast, higher SML and DRCL were observed during stagnant Regional (REG) $(911 \pm 234 \mathrm{~m}$ and $1769 \pm 314 \mathrm{~m}$, respectively) and cold Atlantic (ATL) (965 $\pm 222 \mathrm{~m}$ and $1878 \pm 290 \mathrm{~m}$, respectively) air masses. In addition to being the lowest, the SML during the NAF scenario frequently showed a flat upper boundary through-
\end{abstract}

out the day possibly because of the strong winds from the Mediterranean Sea limiting the midday SML convective growth. The mean backscatter coefficients were calculated at two selected heights representative of middle and top SML portions, i.e. $\beta_{500}=0.59 \pm 0.45 \mathrm{Mm}^{-1} \mathrm{sr}^{-1}$ and $\beta_{800}=0.87 \pm 0.68 \mathrm{Mm}^{-1} \mathrm{sr}^{-1}$ at $500 \mathrm{~m}$ and $800 \mathrm{~m}$ a.g.l., respectively. The highest backscatter coefficients were observed during NAF $\left(\beta_{500}=0.77 \pm 0.57 \mathrm{Mm}^{-1} \mathrm{sr}^{-1}\right)$ when compared with ATL $\left(\beta_{500}=0.51 \pm 0.44 \mathrm{Mm}^{-1} \mathrm{sr}^{-1}\right)$ and REG $\left(\beta_{500}=0.64 \pm 0.39 \mathrm{Mm}^{-1} \mathrm{sr}^{-1}\right)$. The relationship between the vertical change in backscatter coefficient and atmospheric stability $(\partial \theta / \partial z)$ was investigated in the first $3000 \mathrm{~m}$ a.g.l., aiming to study how the unstable, stable or neutral atmospheric conditions of the atmosphere alter the distribution of aerosol backscatter with height over Barcelona. A positive correlation between unstable conditions and enhanced backscatter and vice versa was found.

\section{Introduction}

The planetary boundary layer (PBL) is the lowest part of the atmosphere that contains most atmospheric aerosols and humidity (Stull, 1988). A sound understanding of its main properties (such as height and temporal evolution) and of the factors affecting these properties is essential for meteorological forecasting, climate studies and air quality assessment (Gerbig et al., 2008; Monks et al., 2009). In fact, aerosols once emitted are confined within the PBL where they reside for 
a relatively long time and disperse or accumulate depending on the PBL characteristics such as height or wind fields. During the day the PBL undergoes a diurnal cycle with the highest values around midday when convection is the main mixing force, yielding the shallowest values at night. During the night when convection is not the main mechanism, the PBL structure is largely influenced by surface friction due to vegetation, topography, and urban roughness (Barlow et al., 2011).

The PBL height is usually assessed in two ways: (i) by using in situ vertical profiles of temperature, humidity or wind, and (ii) by employing the aerosols as tracers for laserbased backscatter profilers. The former method is a thermodynamic sounding which determines the top of the PBL through observation of temperature inversions, hydrolapse, or change in wind speed and/or wind direction (e.g. Holzworth, 1964, 1967). The latter method identifies the PBL heights by checking gradients in the aerosol concentrations and is usually applied by means of lidars/ceilometers (e.g. Martucci et al., 2010; Haeffelin et al., 2012). Other widely used remote sounding systems for PBL height determination include sodar, rass and wind profiling radar. A number of methods have been employed to extract the PBL height from active optical methods, providing aerosol backscatter profiles. The decreasing laser backscatter from the aerosols at the interface (transition zone) between the PBL and the free troposphere is the essence of the method. The identified transition zone is a proxy for temperature inversion. These methods involve the analysis of the first or second derivative of the backscatter or the logarithm of the backscatter profile (e.g. Flamant et al., 1997; Menut et al., 1999; Sicard et al., 2006; Martucci et al., 2007), THT (temporal-height tracking) technique (Martucci et al., 2010; Haeffelin et al., 2012), and backscatter variance (e.g. Lammert and Bosenberg, 2006), among others. Methods based on the lidar determination of the PBL height using aerosols as tracers may be adversely affected by the pre-processing of the data, gradient detection, and layer attribution, especially during morning or afternoon transitions or under stable atmospheric conditions (Haeffelin et al., 2012). Conversely, in well-mixed boundary layers, the largest change in the aerosol would match the top of the PBL with the free troposphere above, thus minimizing the uncertainty of retrieving the PBL top. Given the high spatial and temporal resolutions (normally $15 \mathrm{~m}$ and $15 \mathrm{~s}$ ), lidars and ceilometers have become increasingly important for PBL studies and are widely used in networks around the world and especially in Europe (e.g. Flentje et al., 2010; Pappalardo et al., 2004). Earlier studies have dealt with the determination of the evolution of the PBL by means of groundbased laser sensors at both continental sites (e.g. Boers et al., 2000; Clothiaux et al., 2000; Matthias and Bösenberg, 2002; Kalb et al., 2004; Baars et al., 2008) and at coastal sites (e.g. Sicard et al., 2006, 2011; Matthias et al., 2004; Milroy et al., 2011). PBL heights at continental sites up to 2$3 \mathrm{~km}$ a.s.l. have been usually observed in summer (Matthias et al., 2004). Conversely, at sites closer to the coastline no significant differences have been observed in the retrieved heights between summer and winter. Given that the Mediterranean coastal areas are subject to major population density, studies of PBL properties at these locations are of special interest. A number of works have previously focused on the annual and seasonal evolution of the boundary layer at coastal sites in Europe: Barcelona (Sicard et al., 2006, 2011), Athens (Batchvarova and Gryning, 1998), Marseille (Delbarre et al., 2005; Lemonsu et al., 2006), Naples (Boselli et al., 2009) and Rome (Mastrantonio et al., 1994), among others. However, only few works have addressed the determination of the boundary layer diurnal evolution (Martano, 2002; Talbot et al., 2007; De Tomasi et al., 2011). A better characterization of the diurnal evolution of the PBL is needed because of its rule in regulating the extent of dispersion for pollutants.

In this study ceilometer measurements were performed in Barcelona (Spain), one of the most populated and polluted coastal sites in the western Mediterranean Basin (WMB). Earlier lidar measurements performed in Barcelona showed an absence of a marked PBL annual cycle, which is related to the typical summer conditions of the WMB characterised by weak pressure gradients and the development of breeze circulation patterns (Millán et al., 1997; Pérez et al., 2004; Sicard et al., 2006, 2011, 2012). These distinctive characteristics of the WMB together with poor and irregular precipitations and frequent air mass advections from Africa (e.g. Millán et al., 1997; Rodríguez et al., 2001) make the concentration, composition and vertical distribution of the atmospheric aerosols to be highly variable. Consequently, aerosol models and radiative transfer models still suffer from large uncertainties when applied to this region (e.g. Pay et al., 2012).

In this work, we analyse one month of measurements of PBL height and optical properties continuously performed for the first time over Barcelona (Spain), by using a verticalpointing $1064 \mathrm{~nm}$ wavelength CHM15K ceilometer within the framework of the SAPUSS (Solving Aerosol Problems Using Synergistic Strategies) project (Dall'Osto et al., 2012). The main objectives are to provide valuable insights on the PBL structure, evolution and optical properties over Barcelona based on the continuous ceilometer measurements and radiosonde data. We present and discuss the daily cycle of the PBL height and aerosol backscatter at selected heights under three typical atmospheric scenarios affecting the WMB and detected during the duration of the campaign, namely: stagnant Regional (REG), warm African (NAF), and cold Atlantic (ATL). Ground meteorological data and ground $\mathrm{PM}_{1}$ (particles with aerodynamic diameter $<1 \mu \mathrm{m}$ ) concentrations are also presented and correlated with the measured aerosol optical properties as a function of the atmospheric scenarios. The effects of overlying warm African air masses and of strong sea breezes on PBL growth and evolution are discussed. Additionally, ceilometer measurements are correlated with radiosonde data in order to study the effect of 
relative humidity on aerosol backscatter vertical profiles over the coastal area of Barcelona. Finally, the aerosol backscatter coefficient vertical profile and its relationship with unstable/stable atmospheric conditions are also discussed.

\section{Methodology}

\subsection{Measurement site}

Ceilometer measurements were performed at the coastal site of Barcelona (BCN, Spain; 41 $23^{\prime} 24.01^{\prime \prime} \mathrm{N}, 02^{\circ} 6^{\prime} 58.06^{\prime \prime} \mathrm{E}$ ) from 20 September to 19 October 2010. The ceilometer pointing vertically was placed on the roof of an $8 \mathrm{~m}$ high building about $5 \mathrm{~km}$ from the sea in an urban background area (called UB SAPUSS site). Barcelona and its satellite towns (with nearly 4.5 million inhabitants) cover an $8 \mathrm{~km}$ wide strip between the Mediterranean Sea and the coastal mountain range. Moreover, several industrial zones, power plants, and highways are located in the area, making this region to one of the most polluted in the WMB (Querol et al., 2008). Furthermore, during SAPUSS a second ceilometer was also deployed on the terrace of the Fabra observatory $\left(41^{\circ} 25^{\prime} 56^{\prime \prime} \mathrm{N}, 2^{\circ} 07^{\prime} 27^{\prime \prime} \mathrm{E}\right.$; $500 \mathrm{~m}$ a.s.1., called TC SAPUSS site), located in the coastal mountain range behind Barcelona, at about $5 \mathrm{~km}$ from the UB site and pointing horizontally towards the sea (Dall'Osto et al., 2012). A future work will be dedicated to the horizontal ceilometer measurements and presented in this SAPUSS ACP special issue. The main characteristics of the area under study and detailed information on the measurement sites and meteorology in the region during SAPUSS can be found in Dall'Osto et al. (2012).

\subsection{Ceilometer}

The vertical profiles of the lidar signals during the SAPUSS campaign were measured by the single-channel CHM15K (CHM) elastic lidar (ceilometer) manufactured by Jenoptik (Germany). The instrument is designed for continuous cloudbase height determination and aerosol backscatter coefficient measurements during the day and night. The CHM uses a diode-pumped Nd: YAG (neodymium : yttrium aluminum garne) solid state laser emitting low-energy laser pulses $(8 \mu \mathrm{J}$ at $5.58 \mathrm{kHz}$ ) at the fundamental wavelength of $1064 \mathrm{~nm}$. The instrument acquires signals in single photon counting mode, thus increasing the signal-to-noise ratio from altitude where the concentration of aerosol is low. During the SAPUSS campaign, the ceilometer signals were collected every $30 \mathrm{~s}$ with a spatial (vertical) resolution of $15 \mathrm{~m}$. The CHM nominal spatial range is $30-15000 \mathrm{~m}$, with $15 \mathrm{~m}$ vertical resolution (Martucci et al., 2010). The overlap between the emitter's and receiver's field of view is full at $1500 \mathrm{~m}$ (Martucci et al., 2010; Heese et al., 2010; Flentje et al., 2010; Milroy et al., 2011). However, because of the steep slope of the overlap function, the region above $500 \mathrm{~m}$ has $>60 \%$ overlap (Martucci et al., 2010). Moreover, as shown by Milroy et al. (2011) during a multi-sensor comparative study performed at Mace Head (Ireland), the CHM15K signal clearly detects aerosol layers and the PBL internal structure at heights $>500 \mathrm{~m}$. Mainly because of the low power of its laser pulses, the ceilometer has been compared with more powerful lidars designed for tropospheric aerosol studies (Heese et al., 2010; Freudenthaler et al., 2010; Tsaknakis et al., 2011; Haeffelin et al., 2012; Milroy et al., 2011). These comparisons have also been performed to determine the altitude at which the ceilometers are able to detect the aerosols with a signal-to-noise ratio $>1$. Heese et al. (2010) found that the CHM15K can detect aerosol backscatter with signal-to-noise ratio (SNR) $>1$ in the boundary layer and up to $\sim 4 \mathrm{~km}$ during daytime and up to $9 \mathrm{~km}$ during the night. Moreover, Martucci et al. (2010) compared the CHM15k ceilometer with another commercial ceilometer from Vaisala (model CL31) and concluded that the CHM15K has better retrieval skills of the cloud base and a higher sensitivity to aerosols below the cloud base.

\subsubsection{Aerosol backscatter coefficients from ceilometers}

Knowledge of the maximum height with $\mathrm{SNR}>1$ is of paramount importance for the correct retrieval of the backscatter coefficient vertical profiles at different times of the day. The radiation collected by the ceilometer is in fact backscattered from aerosols and molecules and the discrimination of the aerosol contribution requires measurements of the molecular backscatter with SNR $>1$ at altitudes where aerosols are not present. The extinction coefficient is calculated by inverting the $1.064 \mu \mathrm{m}$ lidar power profiles (Klett, 1981; Ferguson and Stephens, 1983) in the region where the signal is not completely attenuated, i.e. up $15 \mathrm{~km}$ for the CHM15K in cloud-free conditions (but subject to the optical thickness of the total column). A lidar ratio of $S=45 \mathrm{sr}$ is assumed for the probing wavelength at $1064 \mathrm{~nm}$, a mixture of continental and maritime aerosols and in the range of $50-80 \%$ of relative humidity (Ackermann, 1998). The raw lidar signal (number of photons) is transformed into received power by use of Plank law combined with the lidar equation at any range $\mathrm{R}$. The obtained lidar power is then corrected for the square of the range $\mathrm{R}$ and normalized by the lidar constant, the latter being calculated directly along the molecular part of the lidar signal (for a non-opaque profile). Because at $1064 \mathrm{~nm}$ the molecular backscatter is very weak, this procedure needs to perform the molecular calibration for integration times not shorter than an hour and preferably during night-time to avoid the solar background. The procedure to obtain the extinction must take into account the effect of the multiple scattering only when high concentration of particles (haze or cloud) occurs along the lidar profile. Multiple scattering $(\eta)$ is in fact a complex function of the field of view of the lidar, the distance of the haze/cloud, the particle concentration, the breadth of particle size distribution and the layer optical depth. The multiple scattering affects the amplitude of the signal received by the lidar at time $t$ and range $\mathrm{R}$ 
by modifying the lidar ratio $\mathrm{S}$ as $\eta \mathrm{S}$ and can cause smaller extinction than in reality $(\eta<1)$. When all the above parameters influencing the value of $\eta$ are negligible the multiple scattering can be neglected by keeping $\eta=1$.

In this work the aerosol backscatter coefficients were retrieved at two selected heights, i.e. at 500 and $800 \mathrm{~m}$ a.g.l. for the entire SAPUSS campaign. The backscatter coefficients at these heights are referred to as $\beta_{500}$ and $\beta_{800}$ hereafter. Moreover, vertical profiles of aerosol backscatter coefficients were retrieved for each day during SAPUSS, integrating the ceilometer signals over $30 \mathrm{~min}$ between 12:00 and 12:30 UTC (Universal Time Coordinated).

\subsubsection{Determination of SML and DRCL heights by ceilometer}

The PBL height and vertical structure above Barcelona was retrieved with standard $30 \mathrm{~s}$ and $15 \mathrm{~m}$ temporal and vertical resolution, respectively, by applying the temporal-height tracking (Martucci et al., 2010; Haeffelin et al., 2012) algorithm to the lidar returns from the CHM15K. The THT is a 1-D (spatial) gradient and time-constrained technique to retrieve the PBL structure. Two layers are retrieved by the THT at each time step: a surface mixed layer (SML, lower layer), which is a proxy for temperature inversion; and a decoupled residual/convective layer (DRCL, upper layer) above which is the free troposphere. The two layers are calculated by applying the THT to an $m$-by- $n$ matrix ( $m=$ number of range gates; $n=$ number of profiles) of attenuated backscatter coefficients, i.e. the natural logarithm of the background-powerrange corrected lidar return. The THT selects the first gradient (SML) along the time-averaged profile with high SNR (averaging interval duration, e.g. $T$ _interv $=10 \mathrm{~min}$ ). The time-averaged profile provides the reference height $\left(H_{\text {ref }}\right)$ for the first $(t=1)$ and the successive $(t>1)$ SML detections. A vertical window centred in $H_{\text {ref }}$ with amplitude normally set to $H_{\text {ref }} \pm 150 \mathrm{~m}$ constrains the SML detection at time steps $t$, $t+1, t+2, \ldots$ and so on until the end of the reference interval $T$ interv. New reference heights are calculated at the beginning of each block of $N * T$ interv $(N=1, \ldots)$ until the end of the dataset. The same procedure is repeated for the upper DRCL. Data from the ceilometer were carefully cloud screened to avoid any bias due to cloud scattering by discarding those raw profiles showing a positive gradient larger than a given threshold.

\subsection{Radiosoundings}

Vertical profiles of temperature, pressure, relative humidity, wind speed and velocity were obtained twice a day from radiosondes (model Vaisala RS92-SGP) launched at 00:00 and 12:00 UTC from a co-located radiosounding system run by the Physics Department of the University of Barcelona. The launching site was about $50 \mathrm{~m}$ from the location of the ceilometer.

\subsubsection{SML height determination by radiosoundings}

For the determination of the SML heights from radiosonde data during SAPUSS, we used the simple parcel method described by Holzworth (1964). With this method the SML height is taken as the equilibrium level of an air parcel with the potential temperature $(\theta)$ calculated at ground level. The potential temperature of an air parcel at pressure $P$ is the temperature that the parcel would acquire if it is adiabatically brought to a standard reference pressure $P_{0}$ (usually 1000 mbar) and is calculated from pressure and temperature data as follows:

$\theta=T \times\left(\frac{1000}{P}\right)^{0.286}$,

where $T\left[{ }^{\circ} \mathrm{K}\right]$ is the actual temperature, $P$ [mbar $]$ is the pressure of the air parcel and 0.286 is the ratio between the gas constant of air $(R)$ and the specific heat capacity at a constant pressure $\left(c_{p}\right)$.

The parcel method allows us to determine the PBL heights in the case of marked inversions, which are usually observed during the day but which are also typical for the nocturnal atmosphere.

\subsection{Other measurements}

Hourly ground ambient temperature, relative humidity, wind speed and direction data were obtained at a meteorological station placed at the Barcelona urban background (UB) measurement site described in Reche et al. (2011) and Dall'Osto et al. (2012) and located at about $200 \mathrm{~m}$ from the ceilometer. Particulate matter (PM) concentrations were obtained during SAPUSS by means of GRIMM (GFZ Reference Internal Magnetic Model) optical counters (model 1107) at the UB site. Subsequently, the PM concentrations from GRIMM were corrected with factors obtained by comparing real time and gravimetric measurements. PM gravimetric measurements on a $24 \mathrm{~h}$ basis were performed every day during SAPUSS with high volume samplers (DIGITEL and MCV at $\left.30 \mathrm{~m}^{3} \mathrm{~h}^{-1}\right)$ with appropriate $\left(\mathrm{PM}_{1}, \mathrm{PM}_{2.5}, \mathrm{PM}_{10}\right)$ cut-off inlets. Aerosol optical depth (AOD) data were obtained from a sunphotometer operating within AERONET (the AERosol Robotic NETwork of ground-based sun- and sky-scanning radiometers; Holben et al., 1998) and located about $50 \mathrm{~m}$ from the ceilometer. The AERONET cloud-screened Level2 data were used in this work. Moreover, data from the sunphotometer were used to retrieve the aerosol Ångström exponents (å), which are a proxy for aerosol size. An aerosol distribution dominated by coarser particles is characterised by values lower than 1 , whereas a larger å (higher than 2) indicates that the scattering is dominated by submicron particles (Schuster et al., 2006). 
Table 1. Characteristics of measurements and variables presented in this work for the whole SAPUSS campaign (ALL) and for each scenario identified during SAPUSS, namely: African, Atlantic, and Regional. Mean values highlighted in bold indicate the variables for which a significant difference was observed among the three different scenarios. SD: standard deviation.

\begin{tabular}{|c|c|c|c|c|c|c|c|c|c|c|}
\hline & & $\begin{array}{l}\text { SML } \\
{[\mathrm{m}]}\end{array}$ & $\begin{array}{l}\text { DRCL } \\
{[\mathrm{m}]}\end{array}$ & $\begin{array}{l}\beta_{500} \\
{\left[\mathrm{Mm}^{-1} \mathrm{sr}^{-1}\right]}\end{array}$ & $\begin{array}{l}\beta_{800} \\
{\left[\mathrm{Mm}^{-1} \mathrm{sr}^{-1}\right]}\end{array}$ & $\begin{array}{l}\mathrm{PM}_{1} \\
{\left[\mu \mathrm{g} \mathrm{m}^{-3}\right]}\end{array}$ & $\begin{array}{l}T \\
{\left[{ }^{\circ} \mathrm{C}\right]}\end{array}$ & $\begin{array}{l}\mathrm{RH} \\
{[\%]}\end{array}$ & $\mathrm{AOD}^{* *}$ & Angst.* \\
\hline \multirow[t]{5}{*}{ ALL } & mean & 904 & 1761 & 0.59 & 0.87 & 12.6 & 18.5 & 64 & 0.08 & 1.2 \\
\hline & $\mathrm{SD}$ & 273 & 363 & 0.45 & 0.68 & 4.4 & 3.8 & 15 & 0.10 & 0.4 \\
\hline & median & 866 & 1798 & 0.45 & 0.68 & 10.9 & 18.6 & 66 & 0.05 & 1.4 \\
\hline & $\min$ & 430 & 829 & 0.06 & 0.05 & 7.7 & 9.3 & 29 & 0.01 & 0.1 \\
\hline & $\max$ & 1916 & 2515 & 3.42 & 4.78 & 26.5 & 26.0 & 94 & 0.48 & 1.7 \\
\hline \multirow[t]{5}{*}{ ATLANTIC } & mean & 965 & 1878 & 0.51 & 0.78 & 9.8 & 17.6 & 55 & $\mathbf{0 . 0 3}$ & 1.3 \\
\hline & SD & 222 & 290 & 0.44 & 0.72 & 1.1 & 3.5 & 13 & 0.02 & 0.3 \\
\hline & median & 905 & 1871 & 0.37 & 0.55 & 9.7 & 17.7 & 55 & 0.03 & 1.3 \\
\hline & $\min$ & 497 & 1130 & 0.09 & 0.11 & 8.1 & 9.3 & 32 & 0.01 & 0.4 \\
\hline & $\max$ & 1673 & 2412 & 2.10 & 3.55 & 13.4 & 24.6 & 81 & 0.10 & 1.7 \\
\hline \multirow[t]{5}{*}{ REGIONAL } & mean & 911 & 1769 & 0.64 & 1.01 & 16.3 & 18.5 & 66 & 0.07 & 1.5 \\
\hline & SD & 234 & 314 & 0.39 & 0.64 & 5.3 & 3.7 & 14 & 0.05 & 0.2 \\
\hline & median & 884 & 1729 & 0.59 & 0.90 & 14.4 & 18.3 & 68 & 0.05 & 1.5 \\
\hline & $\min$ & 483 & 1282 & 0.11 & 0.05 & 8.6 & 11.2 & 29 & 0.02 & 0.7 \\
\hline & $\max$ & 1610 & 2515 & 3.42 & 4.78 & 26.5 & 24.9 & 88 & 0.25 & 1.7 \\
\hline \multirow[t]{5}{*}{ AFRICAN } & mean & 736 & 1573 & 0.77 & 1.14 & 11.6 & 21.5 & 75 & 0.24 & 0.7 \\
\hline & SD & 183 & 428 & 0.57 & 0.72 & 1.6 & 2.5 & 10 & 0.17 & 0.6 \\
\hline & median & 695 & 1568 & 0.62 & 0.81 & 11.5 & 21.7 & 76 & 0.16 & 0.8 \\
\hline & $\min$ & 444 & 849 & 0.11 & 0.08 & 8.7 & 16.5 & 60 & 0.05 & 0.1 \\
\hline & $\max$ & 1261 & 2387 & 2.50 & 3.15 & 15.5 & 26.0 & 94 & 0.48 & 1.6 \\
\hline
\end{tabular}

* Ångström coefficient calculated between $400 \mathrm{~nm}$ and $870 \mathrm{~nm}$; ** AOD at $1020 \mathrm{~nm}$.

\subsection{Classification of air masses during SAPUSS}

During the SAPUSS campaign three different atmospheric scenarios, namely, Regional (REG), Atlantic (ATL), and African (NAF) were observed. These scenarios are not uncommon in the western Mediterranean in summer (i.e. Millan et al., 2000; Pey et al., 2010a; Pandolfi et al., 2011). A brief description of their main characteristics is given below whereas the detailed meteorological picture during SAPUSS and the description of tool used for meteorological analysis are provided in the presenting overview of the SAPUSS campaign (Dall'Osto et al., 2012).

Briefly, the REG scenario typically develops under meteorological conditions characterised by insignificant air mass circulation at the synoptic scale, thus occasionally favouring the accumulation of pollutants. The ATL scenario represents advections from the Atlantic Ocean associated with cold fronts crossing the Iberian Peninsula (IP). This scenario leads to the renovation of accumulated pollution in aged air masses with a consequent reduction in pollutant concentrations. Finally, the NAF scenario identifies the days characterised by air masses from Africa. During the campaign, a total of 9, 7, and 6 days were identified as REG, ATL and NAF, respectively. Moreover, the NAF days were further classified as NAF_E and NAF_W. NAF_E (3 days) is char- acterised by air mass types proceeding from the Sahara and arriving in Barcelona from the E., i.e. from the Mediterranean Sea, whereas NAF_W (3 days) is marked by air masses proceeding from the tropical Atlantic Ocean and arriving in Barcelona from the SW after crossing the Iberian Peninsula (Dall'Osto et al., 2012).

\section{Results}

This section is concerned with the mean characteristics and daily evolutions of SML, DRCL, $\beta_{500}$ and $\beta_{800}$ measured over Barcelona during SAPUSS. Ground meteorological data and ground $\mathrm{PM}_{1}$ concentrations are presented and correlated with the measured aerosol optical properties. The mean values $( \pm 1 \sigma)$ and diurnal cycles of these variables for the entire SAPUSS campaign and for the REG, ATL and NAF scenarios are presented in Table 1 and Fig. $1 \mathrm{a}$ and $\mathrm{b}$. Table 1 also gives the mean AOD and Ångström exponents (å) observed during the campaign.

\subsection{Overall mean characteristics during SAPUSS}

The mean ceilometer SML and DRCL heights over the whole SAPUSS campaign (cf. Table 1) were found to be $904 \pm 273 \mathrm{~m}$ a.g.l. and $1761 \pm 363 \mathrm{~m}$ a.g.l., respectively. This 

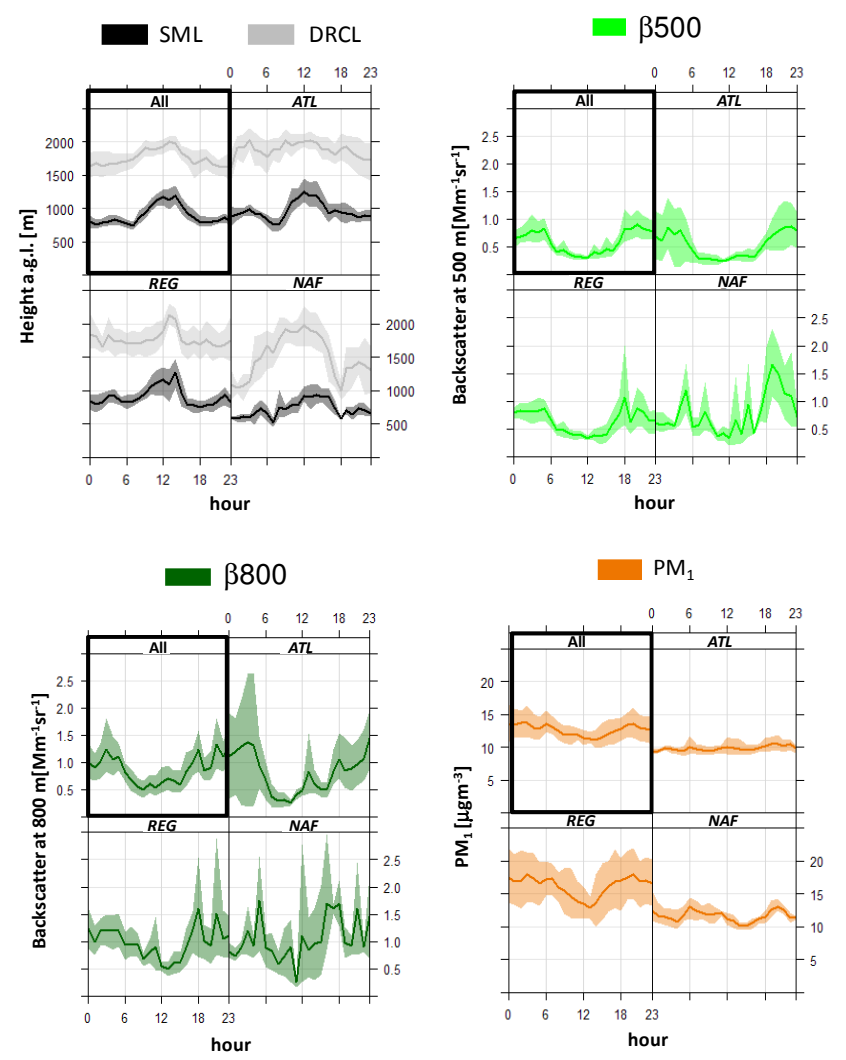

Fig. 1a. Diurnal cycles of SML [m], DRCL [m], aerosol backscatter coefficients at $500 \mathrm{~m}\left(\beta_{500}\right)$ and $800 \mathrm{~m}$ a.g.l. $\left(\beta_{800}\right)\left[\mathrm{Mm}^{-1} \mathrm{sr}^{-1}\right]$, and $\mathrm{PM}_{1}$ concentrations $\left[\mu \mathrm{g} \mathrm{m}^{-3}\right]$ calculated for the entire SAPUSS campaign (All) and for the ATL, REG, and NAF scenarios.

is in agreement with the study of Sicard et al. (2011), which reported a mean mixing layer height - for the same seasonal period of this study - of around $750-1200 \mathrm{~m}$ a.g.l. based on three-year lidar measurements (2007-2009). Mean $\beta_{500}$ and $\beta_{800}$ during SAPUSS were found to be of $0.59 \pm 0.45 \mathrm{Mm}^{-1} \mathrm{sr}^{-1}$ and $0.87 \pm 0.68 \mathrm{Mm}^{-1} \mathrm{sr}^{-1}$, respectively, the latter also being consistent with the mean backscatter at $900 \mathrm{~m}$ reported by Sicard et al. (2011) during the summer period. The mean AOD and Ångström coefficient (å) measured during SAPUSS were around $0.08 \pm 0.10$ and $1.2 \pm 0.4$, respectively, close to the mean values reported for these parameters in Barcelona for the summer period (Pandolfi et al., 2011; Sicard et al., 2011). The mean ground $\mathrm{PM}_{1}$ concentrations $\left(12.6 \pm 4.4 \mu \mathrm{g} \mathrm{m}^{-3}\right)$ during SAPUSS were lower compared with the mean $\mathrm{PM}_{1}$ concentrations (around $17 \mu \mathrm{gm}^{-3}$ ) registered in Barcelona during September and October for the period 2003-2005 (Pey et al., 2010a) but similar to the mean $\mathrm{PM}_{1}$ for the 2008-2011 period (Cusack et al., 2012).

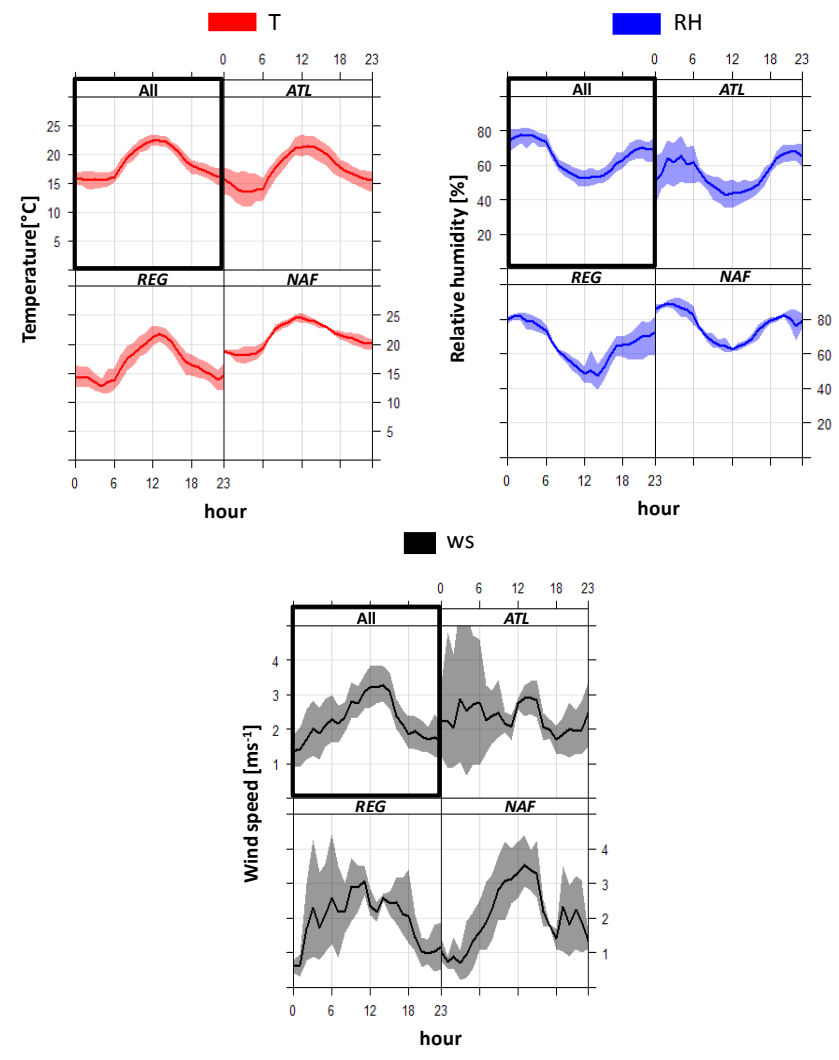

Fig. 1b. Diurnal cycles of ground temperature $(T)\left[{ }^{\circ} \mathrm{C}\right]$, relative humidity (RH) [\%], and wind speed $\left[\mathrm{ms}^{-1}\right]$ calculated for the entire SAPUSS campaign (All) and for the ATL, REG, and NAF scenarios.

\subsubsection{Overall PBL mean diurnal cycles during SAPUSS}

On average, the SML showed a diurnal cycle (ALL; Fig. 1a) with low heights measured at night/early morning $(\sim 800 \mathrm{~m}$ around 18:00-06:00 UTC) and progressively increasing by around $50 \%$ at midday ( $\sim 1200 \mathrm{~m}$ around 12:00-14:00 UTC) when the surface temperature is at its maximum (Fig. 1b). Thus, the increasing convective activity during the warmest hours of the day caused the increase in SML height.

By contrast, opposite diurnal cycles were observed for $\beta_{500}$ and $\beta_{800}$. Figure 1a (ALL) shows the highest values at night $\left(0.77 \mathrm{Mm}^{-1} \mathrm{sr}^{-1}\right.$ and $1.07 \mathrm{Mm}^{-1} \mathrm{sr}^{-1}$, respectively, around 18:00 - 06:00 UTC) and the lowest $\left(0.36 \mathrm{Mm}^{-1} \mathrm{sr}^{-1}\right.$ and $0.67 \mathrm{Mm}^{-1} \mathrm{sr}^{-1}$, respectively) around midday. The difference in backscatter between day and night is probably due to an increase of relative humidity at night (cf. RH in Fig. 1b) leading to a significant hygroscopic growth of aerosols. Radiosonde data were used to calculate the relative difference [\%] in RH between night (00:00 UTC) and day (12:00 UTC) at 500 and $800 \mathrm{~m}$ a.g.l. during SAPUSS. The RH relative differences were then compared with the relative differences [\%] in $\beta_{500}$ and $\beta_{800}$ between night and day. The results are seen in Fig. 2, where the variations in backscatter coefficients 
between night and day are highly correlated with the corresponding variations in $\mathrm{RH}$. Thus $\mathrm{RH}$ is an important parameter contributing to the variation in aerosol backscatters. Moreover, both the lower SML height and dispersion at night (lower wind speed, cf. Fig. 1b) compared with daytime likely favour the accumulation of particles (higher $\mathrm{PM}_{1}$ concentrations at night, cf. Fig. 1a), which may also contribute to the relative increase in backscatter at night.

\subsection{Mean PBL characteristics according to different atmospheric scenarios (ATL, REG and NAF)}

Important differences were observed in the PBL variables (Table 1) for the three scenarios (REG, ATL, NAF) during the SAPUSS study. The highest mean SML and DRCL heights were observed for the ATL scenario at $965 \pm 222 \mathrm{~m}$ and at $1878 \pm 290 \mathrm{~m}$ a.g.l., respectively (Table 1). These heights are slightly higher $(6 \%)$ than the mean SML and DRCL observed during the REG scenario at $911 \pm 234 \mathrm{~m}$ and $1769 \pm 314 \mathrm{~m}$ a.g.1., respectively. Nevertheless, under ATL the mean $\beta_{500}\left(0.51 \pm 0.44 \mathrm{Mm}^{-1} \mathrm{sr}^{-1}\right), \beta_{800}$ $\left(0.78 \pm 0.72 \mathrm{Mm}^{-1} \mathrm{sr}^{-1}\right), \quad \mathrm{PM}_{1} \quad\left(9.8 \pm 1.1 \mu \mathrm{gm}^{-3}\right), \quad$ AOD $(0.03 \pm 0.02)$, and the Angstrom exponent $(1.3 \pm 0.3)$ are lower by respectively 20,24, 40, 60 and $14 \%$ compared with REG (Table 1). The lower $\mathrm{PM}_{1}$ concentrations and AOD during ATL were due to the cleansing effect of the Atlantic advections that reduced the concentration of fine aerosol in the atmosphere. At the same time, the accumulation of pollutants was favoured by the REG episode, when the concentrations of $\mathrm{PM}_{1}$ reached $16.3 \pm 5.3 \mu \mathrm{g} \mathrm{m}^{-3}$. The low concentrations of $\mathrm{PM}_{1}$ for the ATL scenario led to å coefficients higher than those for REG, indicating larger concentrations of coarse particles $(>1 \mu \mathrm{m})$ during ATL. The low relative humidity measured during ATL (Table 1) also contributed to the low $\beta_{500}$ and $\beta_{800}$ during this scenario. Figure 1 in the Supplement shows that the mean RH during ATL is the lowest during SAPUSS at all altitudes, being about $20 \%$ lower in the first one kilometre of height with respect to REG.

By contrast, the lowest mean daily SML and DRCL were detected during the NAF scenario at altitudes of $736 \pm 183$ and $1573 \pm 428 \mathrm{~m}$ a.g.l., respectively (Table 1 ). The SML and DRCL heights during NAF are respectively $25 \%$ and $16 \%$ lower than for the ATL scenario. The mean daily SML during NAF ranged between $609 \pm 128 \mathrm{~m}$ on 8 October 2010 and $798 \pm 106 \mathrm{~m}$ on 7 October 2010 , whereas the minimum and maximum mean daily SML heights during ATL were $895 \pm 209 \mathrm{~m}$ (on 26 September 2010) and $1022 \pm 205 \mathrm{~m}$ (on 28 September 2010), respectively. The shallow SML during NAF was also measured by radiosoundings, which detected mean SML heights at $953 \pm 138 \mathrm{~m}, 925 \pm 183 \mathrm{~m}$, and $800 \pm 206 \mathrm{~m}$ for ATL, REG and NAF, respectively. Thus, significant differences are observed between the NAF scenario and the ATL and REG scenarios in terms of the SML and DRCL heights. The low SML and DRCL under NAF may have been caused by a pushing-down effect of the warm

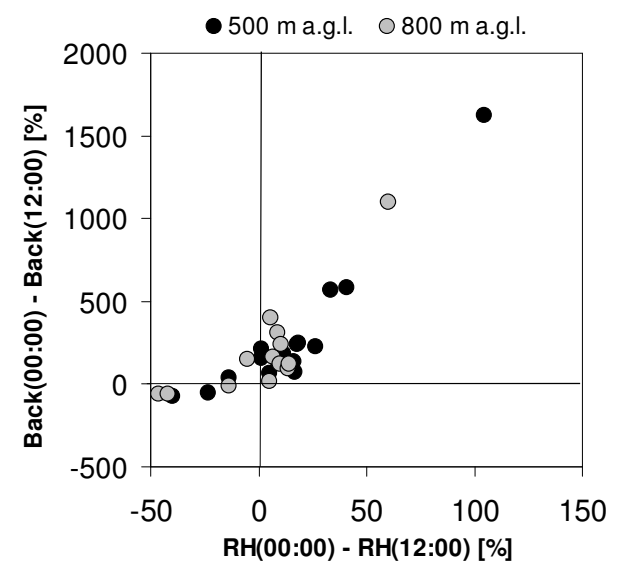

Fig. 2. Relationship between the relative variations [\%] in relative humidity (RH) and aerosol backscatter coefficients (Back) between night (00:00 UTC) and day (12:00 UTC) at $500 \mathrm{~m}$ a.g.l. and $800 \mathrm{~m}$ a.g.1.

overlying African air masses, which changed the temperature profile thus lowering the inversion. Alastuey et al. (2005) reported a significant decrease in the marine boundary layer at Izaña (South of Spain) during an intense Saharan dust outbreak with the overlying African air masses lowering the marine PBL up to $400 \mathrm{~m}$. Similarly, in Barcelona Pérez et al. (2004) reported a case study of low SML height, ranging between about $300 \mathrm{~m}$ and $440 \mathrm{~m}$ during an intense Saharan dust outbreak. The compression of the SML under NAF air masses favoured the transport of the Saharan dust down towards the surface layers by dry deposition, resulting in the increase of $\beta_{500}$ and $\beta_{800}$. Indeed, the NAF scenario registered the highest mean $\beta_{500}\left(0.77 \pm 0.57 \mathrm{Mm}^{-1} \mathrm{sr}^{-1}\right)$ and $\beta_{800}\left(1.14 \pm 0.72 \mathrm{Mm}^{-1} \mathrm{sr}^{-1}\right)$ measured during the campaign (Table 1). The calculated $\beta_{500}$ and $\beta_{800}$ under NAF were, respectively, 20 and $15 \%$ higher than under REG, and 50 and $46 \%$, respectively, higher when compared with ATL. Moreover, as shown in Table 1, the highest mean column integrated AOD $(0.24 \pm 0.17)$ and the lowest mean å $(0.7 \pm 0.6)$ were observed during the NAF scenario, suggesting transport of coarser aerosols from the North Africa region. Figure 2 in the Supplement highlights the relationship between AOD and simultaneous $\beta_{500}$ and $\beta_{800}$ by levels of Ångström exponents, showing that the lowest å were observed during NAF. These were especially low $(<0.12)$ during a dust transport event detected on 7 October 2010, leading to the highest AOD $(>0.3)$ during SAPUSS. Nevertheless, the $\beta_{500}$ and $\beta_{800}$ were relatively low during the event, suggesting transport of dust at higher altitudes over Barcelona. After excluding the data collected on 7 October 2010 , the mean $\mathrm{AOD}, \stackrel{a}{a}, \beta_{500}$ and $\beta_{800}$ during $N A F$ were, respectively, $0.11 \pm 0.04,1.0 \pm 0.3,0.80 \pm 0.59$ and $1.09 \pm 0.71 \mathrm{Mm}^{-1} \mathrm{sr}^{-1}$, strongly suggesting coarse aerosols within the PBL during the whole NAF scenario. Additionally, the presence of dust transported from Africa under NAF 
is also evidenced in Supplement Fig. 1, which shows the multiple-peak structure of the mean aerosol backscatter vertical profile.

Moreover, the low SML and the high RH observed under NAF (around $75 \%$ at ground, cf. Table 1) may also have contributed to the high backscatter observed under NAF. Indeed, Supplement Fig. 1 shows that the mean RH during NAF is the highest during SAPUSS at all altitudes, being on average $47 \%$ higher in the first one kilometre when compared with ATL.

\subsubsection{Mean diurnal cycles according to different atmospheric scenarios (ATL, REG and NAF)}

Large differences among the three scenarios in terms of diurnal cycles were observed for SML, $\beta_{500}$ and $\beta_{800}$ (Fig. 1a). Figure 1a shows that the mean SML during NAF has a flat structure between approximately 11:00 and 16:00 UTC compared with the ATL and REG scenarios, which by contrast show clear SML maxima around midday. The flat SML structure under NAF is present despite the high surface temperatures at midday under NAF with respect to REG and ATL (cf. Fig. 1b). The mean SML heights between 11:00 and 16:00 UTC were $1133 \pm 354 \mathrm{~m}, 1107 \pm 313 \mathrm{~m}$, and $916 \pm 168 \mathrm{~m}$ for ATL, REG and NAF, respectively, with the lowest standard deviation (18\%) observed for the NAF scenario compared with ATL $(31 \%)$ or REG $(28 \%)$. The flat structure observed for SML around midday during NAF is probably due to the increase in the mean wind velocities within the SML preventing the vertical development of the SML. When differentiating NAF into NAF_E and NAF_W, two different sub scenarios were found. The NAF days were divided into two main categories; namely, NAF_E (7, 8, and 9 October 2010, NAF air masses arriving from the east) and NAF_W (22-23 September and 3 October 2010, NAF air masses arriving from the west, Dall'Osto et al., 2012). Figure 3 shows the SML and DRCL diurnal cycles from the ceilometer and the SML heights from the radiosoundings at 12:00 UTC for the NAF_W days (Fig. 3a) and the NAF_E days (Fig. 3b).

During the NAF_W days the SML shows a certain convective growth around midday. Nevertheless, the SML growth under NAF_W was not as strong as during the ATL and REG scenarios because of the overlying African air masses. Conversely, a flat SML structure throughout the $24 \mathrm{~h}$ was observed under the NAF_E days. This is likely due to the strong winds blowing continuously from the Mediterranean Sea preventing the vertical development of the SML. Figure 3 shows that the mean wind direction (wd) and speed (ws) within the first kilometre a.g.l. during NAF_W are around $214 \pm 39$ degrees (southwest) and $3.6 \pm 1.7 \mathrm{~ms}^{-1}$, respectively, whereas during NAF_E the mean wd and ws are $73 \pm 17$ degrees (east) and $6.9 \pm 0.9 \mathrm{~ms}^{-1}$, respectively. The low standard deviations indicated relatively constant vertical profiles of wind speed and direction during both NAF_W and NAF_E scenarios. The mean ws within the first kilometre during NAF_E doubled the mean wind velocity under NAF_W, REG $\left(3.2 \pm 1.2 \mathrm{~ms}^{-1}\right)$ and ATL $\left(3.8 \pm 1.5 \mathrm{~ms}^{-1}\right)$ days, probably preventing the development of the SML.

The mean diurnal cycles of $\beta_{500}$ and $\beta_{800}$ during ATL, REG and NAF are fairly similar (Fig. 1a), showing higher values at night and minima during daytime. However, the diurnal cycles of backscatter under NAF also show the presence of multiple peaks due to transported dust from Africa.

Finally, the importance of $\mathrm{RH}$ variation in determining the scattering properties of aerosols can be assessed here by looking at the diurnal cycles of $\beta_{500}, \beta_{800}, \mathrm{PM}_{1}$ and RH under ATL (Fig. 1a, b). During ATL both $\beta_{500}$ and $\beta_{800}$ show clear diurnal cycles whereas the $\mathrm{PM}_{1}$ concentrations show no diurnal cycle, being fairly constant throughout the $24 \mathrm{~h}$. Conversely, under the NAF and REG scenarios, variations in the diurnal cycles in $\mathrm{PM}_{1}$ concentrations and $\beta_{500}$ and $\beta_{800}$ are observed. Figure 1a shows that the ground wind velocity during ATL was fairly high and constant throughout the day. This is probably the most important variable determining the low daily variability in $\mathrm{PM}_{1}$ concentrations. Conversely, the $\mathrm{RH}$, for which a clear diurnal cycle is observed under ATL, is the main parameter driving the diurnal cycles of aerosol backscatter (cf. Fig. 1b).

\subsection{Comparison of SML height: ceilometer vs radiosonde}

Figure 4 shows the relationship between the SML heights estimated from radiosoundings and ceilometer data at 12:00 UTC for the whole SAPUSS campaign and for each scenario. Such comparison is important given that both lidars and radiosoundes are widely used techniques for the determination of the SML height. A good correlation $\left(R^{2}=0.80\right.$; $p$ value $<0.05)$ is observed between the retrieved SML heights during the whole SAPUSS campaign (ALL). On average, the SML heights from radiosoundings were lower than those from the ceilometer by around $145 \pm 145 \mathrm{~m}$ (error calculated as one standard deviation of the data). Recently, Haeffelin et al. (2012) showed that lidar/ceilometers tend to overestimate the mixing heights compared with radiosoundings. The deviations we observed in this study were of the same sign and range of the deviations reported by Haeffelin et al. (2012). Good correlations are also observed specifically for each scenario, with coefficients of determination $R^{2}$ ranging from $0.75(\mathrm{REG} ; p$ value $<0.1$ ) to $0.96(\mathrm{NAF}$; $p$ value $<0.4)$. On average, the highest differences are detected for the REG and ATL scenarios with values around $166 \pm 125 \mathrm{~m}$ and $249 \pm 43 \mathrm{~m}$, respectively, whereas during the NAF scenario the difference is small and slightly negative $(-42 \pm 41 \mathrm{~m})$. The reason for the good agreement observed between radiosondes and ceilometer in estimating the SML heights during NAF could be the differential advection of air masses at different heights observed under the NAF scenario. The 5-day back-trajectories ending in Barcelona at 

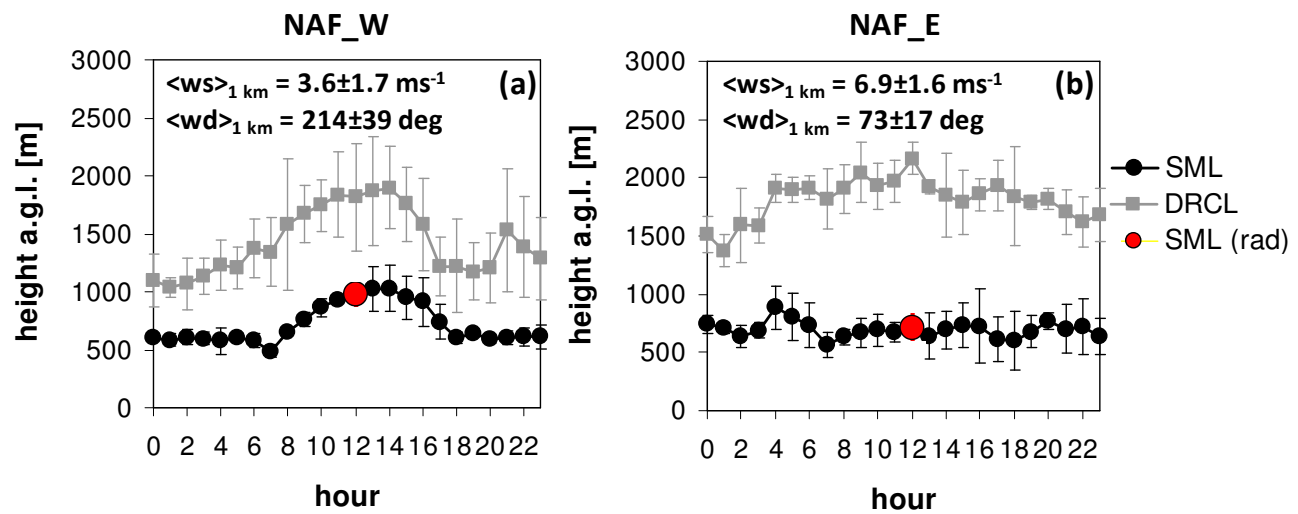

Fig. 3. Mean SML (black dotted line) and DRCL (grey dotted line) diurnal cycles from ceilometer and SML heights from radiosoundings retrieved at 12:00 UTC (red dot) averaged during the NAF_W days (Fig. 3a) and the NAF_E days (Fig. 3b). Error bars represent one standard deviation of the means. $<w s>1 \mathrm{~km}$ and $<\mathrm{wd}>1 \mathrm{~km}$ stand for mean wind speed and direction, respectively, averaged within the first kilometre of height from radiosoundings.

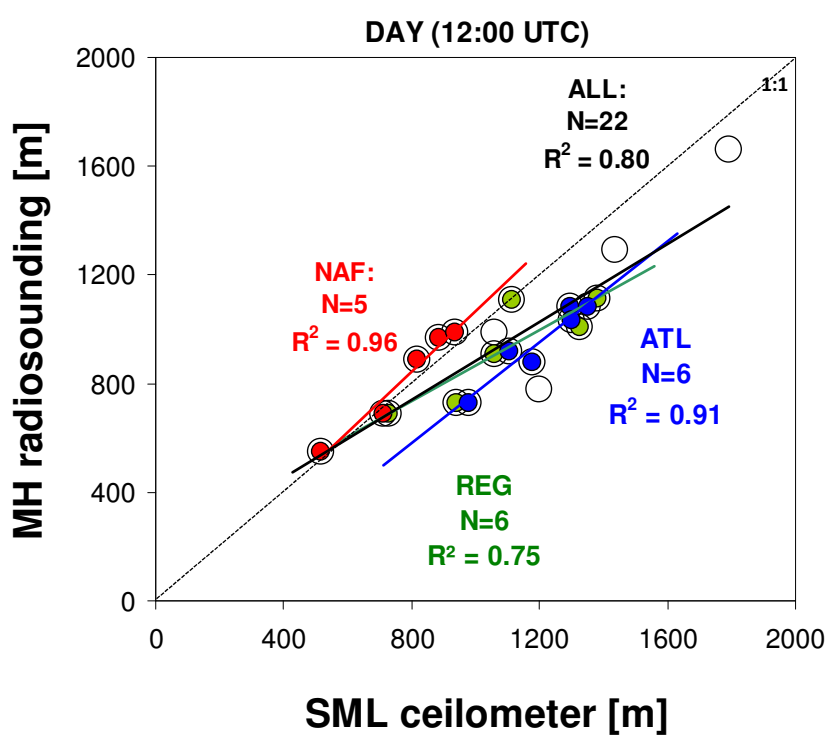

Fig. 4. Correlation between SML heights retrieved from ceilometer and radiosoundings at 12:00 UTC for the whole SAPUSS campaign (open circles) and separately for the Regional (REG; green circles), African (NAF; red circles), and Atlantic (ATL; blue circles) scenarios. $N$ : number of aerosol backscatter and potential temperature vertical profile pairs; $R^{2}$ : coefficient of determination.

12:00 UTC and calculated for the NAF days (two examples are shown in Fig. S3 in the Supplement) display the differential advection with the air mass ending at $1000 \mathrm{~m}$ a.g.l. clearly coming from Africa and those at lower altitudes having different origins. This differential advection may have caused an abrupt change in physical (aerosol) and thermodynamic (potential temperature) properties at the top of the SML, thus minimizing the differences typically observed between ceilometer and radiosondes in estimating the SML height. By contrast, the opposite trend is seen for the ATL scenario where the air masses had the same origin at the altitudes considered (cf. Supplement Fig. 4) and the largest difference between the SML heights can be observed.

\subsection{Relationship between aerosol backscatter vertical profile and thermodynamic states of the atmosphere}

Figure 4 shows that the changes in the thermodynamic state of the atmosphere at the top of the SML are closely correlated with the variations in the aerosol load. The correlation is studied in greater depth here by comparing the potential temperature and the aerosol backscatter vertical profiles from $500 \mathrm{~m}$ up to $3000 \mathrm{~m}$ a.g.l. This analysis seeks to show how the unstable, stable or neutral atmospheric conditions of the atmosphere alter the distribution of aerosol backscatter with height. Fourteen vertical profiles of aerosol backscatter integrated between 12:00 and 12:30 UTC (no clouds included) were selected and compared with the potential temperature profiles from radiosondes launched at 12:00 UTC. The 14 profile pairs were interpolated to a vertical resolution of $30 \mathrm{~m}$ and were averaged to obtain one pair of mean aerosol backscatter and potential temperature vertical profiles. Figure 5a shows the relationship between the first derivatives with height of the mean aerosol backscatter and potential temperature profiles, ranging between $500 \mathrm{~m}$ and $3000 \mathrm{~m}$ a.g.l. with $\Delta z=30 \mathrm{~m}$. Figure $5 \mathrm{~b}$ is calculated by averaging the first derivatives every $200 \mathrm{~m}(\Delta z=200)$ and error bars in Fig. $5 \mathrm{~b}$ indicate \pm 1 standard deviation of the means. Figure $5 \mathrm{c}$ and $\mathrm{d}$ are similar to Fig. $5 \mathrm{a}$ and $\mathrm{b}$, respectively, and were obtained by using a subset of 4 profile pairs that showed different characteristics as described below. The NAF days were excluded from this analysis because the gradients of the backscatter coefficient in the presence of aerosol layers of different origin were strong enough to impair the backscatter-temperature relationship. The mean vertical profiles of backscatter, potential temperature and 

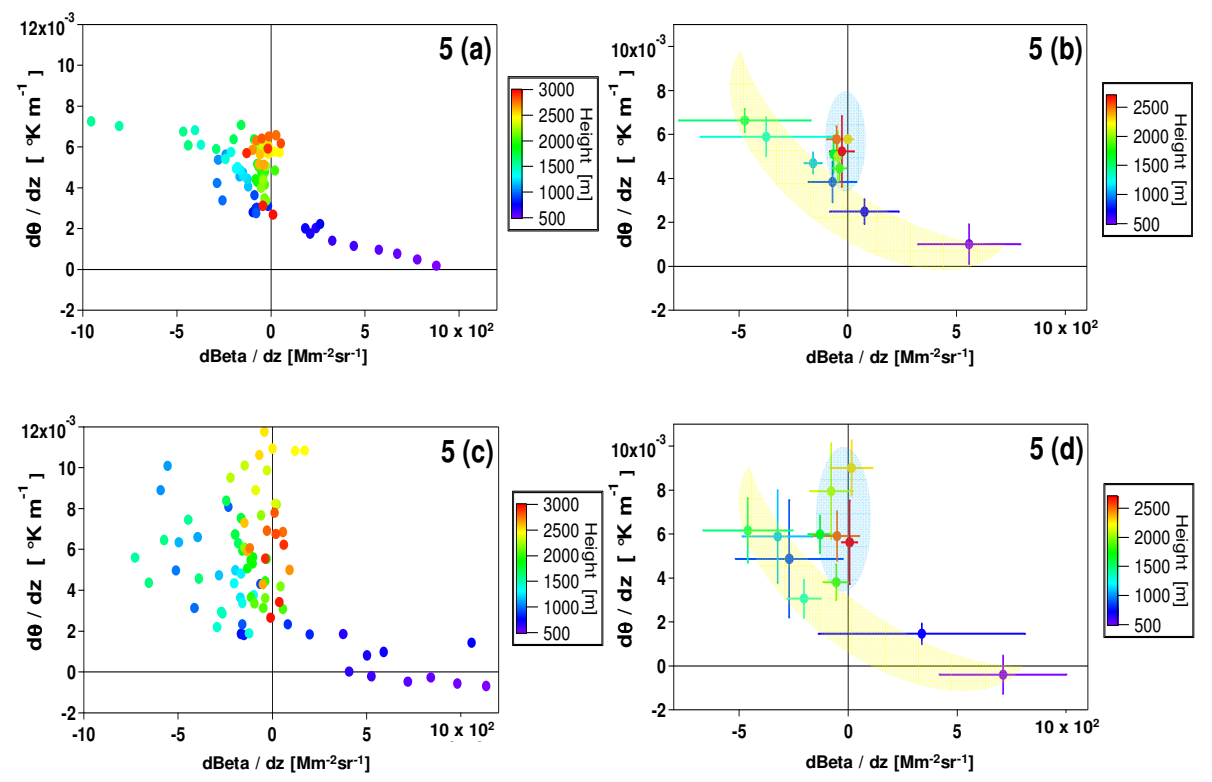

Fig. 5. Relationship between the first derivatives as a function of the height of aerosol backscatter (Beta) and potential temperature $(\theta)$ vertical profiles: (a) by using the points from $500 \mathrm{~m}$ to $3000 \mathrm{~m}$ a.g.1. (30 m vertical resolution) of one pair of Beta and $\theta$ vertical profiles obtained by averaging 14 available profile pairs; (b) by averaging the points of (a) every $200 \mathrm{~m}$ with the error bars indicating \pm 1 standard deviation of the means; (c) by using the points from $500 \mathrm{~m}$ to $3000 \mathrm{~m}$ a.g.1. ( $30 \mathrm{~m}$ vertical resolution) of one pair of Beta and $\theta$ vertical profiles obtained by averaging a subset of 4 profile pairs; (d) by averaging the points of (c) every $200 \mathrm{~m}$ with the error bars indicating \pm 1 standard deviation of the means. Yellow and blue coloured areas in (b) and (d) indicate the SML+DRCL and the free troposphere, respectively.

relative humidity calculated by averaging the 14 profiles are shown in Fig. 5 in the Supplement. Figure 5a and b show that the backscatter coefficient increases with height $(d \mathrm{Beta} / d z$ $>0$ ) at altitudes (between about 500 and $900 \mathrm{~m}$ ) where $\theta$ is fairly constant or increases slightly with height $(d \vartheta / d z \sim 0)$. This first altitude range represents the mean SML height. In this range, convection rapidly mixes the atmosphere with the result that $\theta$ is fairly constant with height and the atmosphere is characterised by neutral stability. Above $\sim 1000 \mathrm{~m}$ and up to $\sim 1700 \mathrm{~m}$ the backscatter coefficient decreases with height $(d$ Beta/dz $>0)$, showing a slightly negative slope around 900-1100 m, which becomes steeper with increasing height up to $1500-1700 \mathrm{~m}$. This altitude range represents the atmospheric region between the top of SML and the DRCL. Conversely, the potential temperature increases with height from $1000 \mathrm{~m}$ up to $1700 \mathrm{~m}(d \vartheta / d z>0)$, showing steeper positive slopes with increasing altitudes. These conditions give rise to stable stratified conditions with suppressed vertical motions. The increasing and decreasing trend of aerosol backscatter coefficient as a function of the potential temperature between $500 \mathrm{~m}$ and $1700 \mathrm{~m}$ is highlighted by the yellow area in Fig. 5b. From $\sim 1700 \mathrm{~m}$ up to $3000 \mathrm{~m}$ the backscatter coefficient shows a very small negative derivative, indicating a gentle decrease in aerosol backscatter with height in the free troposphere. By contrast, at these heights the potential temperature increases showing steeper slopes with altitude $(d \vartheta / d z>0)$. The behaviour of both variables in the free troposphere is highlighted by the blue area in Fig. 5 b.
The anticorrelation/correlation reported in Fig. 5 changes with height, allowing for the identification of SML, residual layer (RL), DRCL, and free troposphere (FT). Figure 5c and $\mathrm{d}$ were obtained by using a subset of 4 profile pairs when the lower atmosphere showed a certain degree of instability $(d \theta / d z<0)$ up to about $600 \mathrm{~m}$ a.g.l. Nevertheless, the backscatter behaves in the same way as it does under neutral conditions and increases with height $(d$ Beta/ $d z>0)$. The observed increase of aerosol backscatter within the SML at midday irrespective of the thermodynamic states of the atmosphere is probably due to the increase with height in relative humidity within the SML. Figure $6 \mathrm{a}$ and $\mathrm{b}$ show the relationship between the first derivatives of backscatter coefficient and relative humidity profiles as a function of height. Figures $6 \mathrm{a}$ and $6 \mathrm{~b}$ show that both backscatter and relative humidity increase with height between $500 \mathrm{~m}$ and $900 \mathrm{~m}$ (within the SML) and decrease with height starting from $900 \mathrm{~m}$. In the free troposphere (blue coloured area) the backscatter decreases only slightly with height, with the RH showing steeper slopes with respect to backscatter.

\section{Discussion and conclusion}

During the SAPUSS (Solving Aerosol Problems by Using Synergistic Strategies) project a vertical-pointing 1064$\mathrm{nm}$ wavelength CHM15K ceilometer was deployed with the aim of determining the boundary layer structure, evolution 

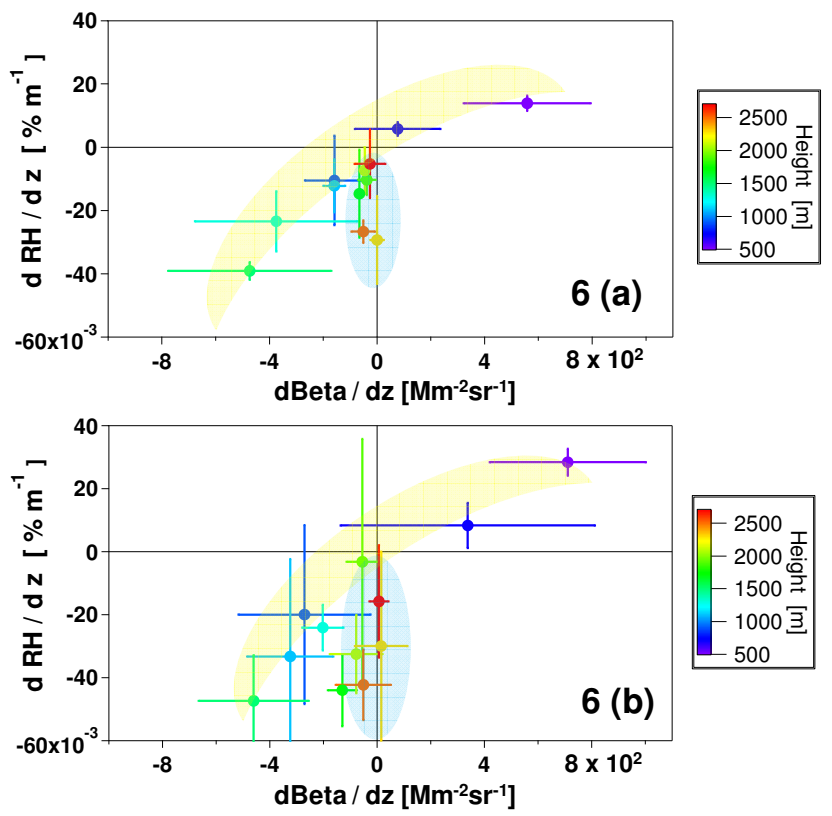

Fig. 6. Relationship between the first derivatives as a function of the height of aerosol backscatter (Beta) and relative humidity (RH) vertical profiles: (a) by using the points from $500 \mathrm{~m}$ to $3000 \mathrm{~m}$ a.g.l. (averaged every $200 \mathrm{~m}$ ) of one pair of Beta and RH vertical profiles obtained by averaging 14 available profile pairs; (b) by using the points from $500 \mathrm{~m}$ to $3000 \mathrm{~m}$ a.g.l. (averaged every $200 \mathrm{~m}$ ) of one pair of Beta and RH vertical profiles obtained by averaging a subset of 4 profile pairs. Error bars indicate \pm 1 standard deviation of the means. Yellow and blue coloured areas indicate the SML+DRCL and the free troposphere, respectively.

and optical properties over the coastal area of Barcelona. Ceilometer data has been thoroughly analysed in order to provide valuable insights on (1) the impact that three typical atmospheric scenarios (African dust outbreak, Atlantic advection, Regional recirculation) have on the PBL over a coastal Mediterranean urban area in the WMB, and (2) the possible explanations for the observed increase of aerosol backscatter with height within the SML irrespective of the thermodynamic states of the atmosphere. Our findings can be summarized as follows:

1. PBL maximum height $(\mathrm{H})$ and daily variations (DV) were strongly dependent on air mass types, ranging from the highest $\mathrm{H}$ - strongest DV during the ATL to the lowest $\mathrm{H}$ - weakest DV during the NAF. The observed differences in the PBL structure over Barcelona were due to the concomitance of different factors. The presence of warm African air masses above colder local air changed the temperature profile thus lowering the height of the inversion. As a result the mean SML height during NAF was $25 \%$ lower than the ATL scenario. Previous studies conducted in Barcelona have related the lack of a clear PBL-height annual cycle to the typical summer conditions of the WMB characterised by weak pressure gradients and the development of breeze circulation patterns (Sicard et al., 2011). Even though the breeze pattern is a recognized phenomenon affecting the growth of PBL at coastal sites, the higher occurrence and the intensity of African dust episodes in the WMB in summer (10-20\% of the days, Pey et al., 2010b) may also contribute to prevent the development of the PBL. The current result will be a motivation to further investigate the possible relationship between PBL height, PBL temperature profiles and African dust episodes.

2. The analysis of the relationship between the SML heights estimated by the ceilometer (SMLh_ceil) and radiosoundings (SMLh_rad) at 12:00 UTC revealed another interesting characteristic of PBL under NAF. On average the SMLh_rad were lower than the SMLh_ceil by around $166 \mathrm{~m}$ and $249 \mathrm{~m}$ during REG and ATL, respectively, whereas during the NAF scenario the difference was smaller $(-42 \mathrm{~m})$. We argue that a possible reason for the good agreement between SMLh_ceil and SMLh_rad during NAF may be the presence of abrupt changes in the vertical profiles of backscatter and potential temperature at the SML top caused by the differential advection of air masses above Barcelona during NAF. These abrupt changes could reduce the uncertainties in SML top retrieval from the two techniques. The mean slopes of the lidar backscatter and potential temperature profiles at the top of the SML during NAF were $-38 \pm 7 \times 10^{2} \mathrm{Mm}^{-2} \mathrm{sr}^{-1}$ and $+18 \pm 7 \times 10^{-3}{ }^{\circ} \mathrm{Km}^{-1}$, respectively, at 12:00 UTC. By comparing these values with Fig. 5, we can observe that the potential temperature's and the backscatter's first derivatives during NAF were out of the range of values reported in Fig. 5. These values corroborate with the hypothesis that the differential advection caused abrupt physical and thermodynamic changes at the SML top, which accounted for the good agreement between SMLh_ceil and SMLh_rad during NAF.

3. Aerosol backscattering coefficients (BSC) were highly variable, with the highest values influenced by both African dust intrusions (NAF) and regional anthropogenic pollution (REG). The lower SML under NAF favoured the transport of the Saharan dust down towards the surface layers by dry deposition. As a consequence, the NAF scenario registered the highest mean $\beta_{500}$ and $\beta_{800}$ measured during the campaign, which were $20 \%$ and $15 \%$, respectively higher than under REG and $50 \%$ and $46 \%$, respectively, higher compared with ATL.

4. In the portion of the atmosphere characterised by neutral thermodynamic stability conditions $(d \theta / d z \sim 0)$ at midday, the BSC increased in parallel with RH with altitude. By contrast, under the stable stratified conditions $(d \theta / d z>0)$ above the SML, BSC decreased with falling RH with height. The increase in BSC with 
altitude was also detected under unstable atmospheric conditions $(d \theta / d z<0)$. This analysis revealed that at midday the aerosol backscatter over the coastal site of Barcelona increases with height from near ground to the SML top irrespective of the thermodynamic states of the atmosphere. At midday the portion of the atmosphere characterised by neutral thermodynamic stability conditions $(d \theta / d z \sim 0)$ is assumed to be well mixed and represents the volume of air into which pollutants can be dispersed. The increasing backscatter with height within the SML at midday was due to the increase with height of RH, which through aerosol swelling, increases the effective aerosol cross section. When lidar data are used to estimate the PBL AOD from extinction measurements, a common assumption made is to assume the extinction to be a flat extrapolation at ground of the extinction profile at the range of full overlap. On the base of 1 month of radiosundings performed during SAPUSS, we observed that the $\mathrm{RH}$ at Barcelona monotonically increases with height by around $40 \%$ from ground to the SML top. Thus, the observed strong RH dependence of backscatter vertical profile should be taken into account for PBL AOD calculation from lidar extinction data.

In summary, the continuous online measurements of the PBL characteristics and aerosol optical properties taken during the SAPUSS project were proven to be valuable. Further studies are necessary to improve our knowledge on the relationship among African dust outbreaks, temperature's vertical profile and PBL height.

\section{Supplementary material related to this article is available online at: http://www.atmos-chem-phys.net/13/ 4983/2013/acp-13-4983-2013-supplement.pdf.}

Acknowledgements. This study was supported by FP7-PEOPLE2009-IEF, Project number 254773, SAPUSS - Solving Aerosol Problems Using Synergistic Strategies (Marie Curie Actions - Intra European Fellowships. Manuel Dall'Osto), the Spanish Ministry of Science and Innovation and FEDER funds under the project PRISMA (CGL2012-39623-C02/00), GRACCIE (CSD2007-00067), VAMOS (CLG2010-19464), and the Generalitat de Catalunya (2009 SGR8). M. Pandolfi was funded by the JAEDoc CSIC program, co-funded by the European Social Fund (ESF). The authors gratefully acknowledge the NOAA Air Resources Laboratory (ARL) for the provision of the HYSPLIT transport and dispersion model and/or READY website (http://www.arl.noaa.gov/ ready.html) used in this publication. Thanks are also due to José Ma. Baldasano and staff for their help in establishing and maintaining the Barcelona AERONET measurement site. The authors wish to thank the Catalan Meteorological Service for providing the BCN radiosounding data. The authors wish to thank D. C. Carslaw and K. Ropkins for providing the Openair software used in this paper (Carslaw and Ropkins, 2012; Carslaw, 2012).
Edited by: R. Vecchi

\section{References}

Ackermann, J.: The extinction-to-backscatter ratio of tropospheric aerosol: a numerical study, J. Atmos. Ocean. Technol., 15, 1043 1050, 1998.

Alastuey, A., Querol, X., Castillo, S., Escudero, M., Avila, A., Cuevas, E., Torres, C., Romero, P.M., Exposito, F., García, O., Diaz, J. P., Van Dingenen, R., Putaud J. P.: Characterisation of TSP and $\mathrm{PM}_{2.5}$ at Izaña and Sta. Cruz de Tenerife (Canary Islands, Spain) during a Saharan Dust Episode (July 2002), Atmos. Environ., 39, 4715-4728, 2005.

Baars, H., Ansmann, A., Engelmann, R., and Althausen, D.: Continuous monitoring of the boundary-layer top with lidar, Atmos. Chem. Phys., 8, 7281-7296, doi:10.5194/acp-8-7281-2008, 2008.

Barlow, J. F., Dunbar, T. M., Nemitz, E. G., Wood, C. R., Gallagher, M. W., Davies, F., O'Connor, E., and Harrison, R. M.: Boundary layer dynamics over London, UK, as observed using Doppler lidar during REPARTEE-II, Atmos. Chem. Phys., 11, 2111-2125, doi:10.5194/acp-11-2111-2011, 2011, 2011.

Batchvarova, E. and Gryning, S. E.: Wind climatology, atmospheric turbulence and internal boundary-layer development in Athens during the MEDCAPHOT-TRACE experiment, Atmos Environ., 32, 2055-2069, 1998.

Boers, R., Russchenberg, H., Erkelens, J., and Venema, V.: Ground-based remote sensing of stratocumulus properties during CLARA, J. Appl. Meteor., 39, 169-181, 2000.

Boselli, A., Armenante, M., D’Avino, L., D’Isidoro, M., Pisani, G., Spinelli, N., Wang, X.: Atmospheric aerosol characterization over Naples during 2000-2003 EARLINET project: Planetary boundary-layer evolution and layering, Bound.-Layer Meteorol., 132, 151-165, 2009.

Carslaw, D. C.: The openair manual - open-source tools for analysing air pollution data, Manual for version 0.7-0, King's College London, 2012.

Carslaw, D. C. and Ropkins, K.: openair - an R package for air quality data analysis, Environ. Modell. Softw., 27-28, 52-61, 2012.

Clothiaux, E. E., Ackerman, T. P., Mace, G. C., Moran, K. P., Marchand, R. T., Miller, M. A., and Martner, B. E.: Objective determination of cloud heights and radar reflectivities using a combination of active remote sensors at the ARM CART site, J. Appl. Meteor., 39, 645-665, 2000.

Cusack, M., Alastuey, A., Pérez, N., Pey, J., and Querol, X.: Trends of particulate matter $\left(\mathrm{PM}_{2.5}\right)$ and chemical composition at a regional background site in the Western Mediterranean over the last nine years (2002-2010), Atmos. Chem. Phys., 12, 8341-8357, doi:10.5194/acp-12-8341-2012, 2012.

Dall'Osto, M., Querol, X., Alastuey, A., Minguillon, M. C., Alier, M., Amato, F., Brines, M., Cusak, M., Grimalt, J. O., Karanasiou, A., Moreno, T., Pandolfi, M., Pey, J., Reche, C., Ripoll, A., Tauler, R., Van Drooge, B. L., Viana, M., Harrison, R. M., Gietl, J., Beddows, D., Bloss, W., O’Dowd, C., Ceburnis, D., Martucci, G., Ng, S., Worsnop, D., Wenger, J., Mc Gillcuddy, E., Sudou, J., Healy, R., Lucarelli, F., Nava, S., Jimenez, J. L., Gomez Moreno, F., Artinano, B., Prevot, A. S. H., Pfaffenberger, L., Frey, S., Wilsenack, F., Casabona, D., Jiménez-Guerrero, P., Gross, D., and Cotz, N.: Presenting SAPUSS: solving aerosol problem by 
using synergistic strategies at Barcelona, Spain, Atmos. Chem. Phys. Discuss., 12, 18741-18815, doi:10.5194/acpd-12-187412012, 2012.

Delbarre, H., Augustin, P., Saïd, F., Campistron, B., Benech, B., Lohou, F., Puygrenier, V., Moppert, C., Cousin, F., Freville, P., and Frejafon, E.: Ground-based remote sensing observation of the complex behaviour of the Marseille boundary layer during ESCOMPTE, Atmos. Res., 74, 403-433, 2005.

De Tomasi, F., Miglietta, M., and Perrone, M. R.: The Growth of the Planetary Boundary Layer at a Coastal Site: a Case Study, Bound.-Layer Meteorol., 139, 521-554, 2011.

Ferguson J. A. and Stephens, D. H.: Algorithm for inverting lidar returns, Appl. Opt., 22, 3673-3675, 1983.

Flamant, C., Pelon, J., Flamant, P. H., and Durand, P.: Lidar determination of the entrainment zone thickness at the top of the unstable marine atmospheric boundary layer, Bound.-Layer Meteorol., 83, 247-284, 1997.

Flentje, H., Heese, B., Reichardt, J., and Thomas, W.: Aerosol profiling using the ceilometer network of the German Meteorological Service, Atmos. Meas. Tech. Discuss., 3, 3643-3673, doi:10.5194/amtd-3-3643-2010, 2010.

Freudenthaler, V., Gross, S., Engelmann, R., Mattis, I., Wandinger, U., Pappalardo, G., Amodeo, A., Giunta, A., D'Amico, G., Chaikovsky, A., Osipenko, F., Slesar, A., Nicolae, D., Belegante, L., Talianu, C., Serikov, 5 I., Linne, H., Jansen, F., Wilson, K., de Graaf, M., Apituley, A., Trickl, T., Giehl, H., and Adam, M.: EARLI09 -Direct intercomparison of eleven EARLINET lidar, 25th International Laser Radar Conference (ILRC), St. Petersburg, Russia, S7O-05, pag. 61, available at: http://ilrc25.iao.ru/ conference/program, 2010.

Gerbig, C., Körner, S., and Lin, J. C.: Vertical mixing in the atmospheric tracer transport models: error characterization and propagation, Atmos. Chem. Phys., 8, 591-602, doi:10.5194/acp-8591-2008, 2008.

Haeffelin, M., Angelini, F., Morille, Y., Martucci, G., Frey, S., Gobbi, G. P., Lolli, S., O’Dowd, C. D., Sauvage, L., XuerefRémy, I., Wastine, B., and Feist, D. G.: Evolution of MixingHeight Retrievals from Automatic Profiling Lidars and Ceilometers in View of Future Integrated Networks in Europe, Bound.Layer Meteorol., 143, 49-75, 2012.

Heese, B., Flentje, H., Althausen, D., Ansmann, A., and Frey, S.: Ceilometer lidar comparison: backscatter coefficient retrieval and signal-to-noise ratio determination, Atmos. Meas. Tech., 3, 1763-1770, doi:10.5194/amt-3-1763-2010, 2010.

Holben, B. N., Eck, T. F., Slutsker, I., Tanre, D., Buis, J. P., Setzer, A., Vermote, E., Reagan, J. A., Kaufman, Y. J., Nakajima, T., Lavenu, F., Jankowiak, I., and Smirnov, A.: AERONET - A federated instrument network and data archive for aerosol characterization, Remote Sens. Environ., 66, 1-16, 1998.

Holzworth, C. G.: Estimates of mean maximum mixing depths in the contiguous United States, Mon. Weather Rev., 92, 235-242, 1964.

Holzworth, G.: Mixing depths, wind speeds and air pollution potential from selected locations in the United States, J. Appl. Meteorol., 6, 1039-1044, 1967.

Kalb, C. P., Dean, A. R., Peppler, R. A., and Sonntag, K. L.: Intercomparison of cloud base height at the ARM Southern Great Plains site, Presented 14th Atmospheric Radiation Measurement (ARM) Science Team Meeting, Albuquerque, NM, US Dept. of
Energy, 2004.

Klett, J. D.: Stable analytical inversion solution for processing lidar returns, Appl. Opt., 20, 211-220, 1981.

Lammert, A. and Bosenberg, J.: Determination of the convective boundary layer height with laser remote sensing, Bound.-Layer Meteorol., 119, 159-170, 2006.

Lemonsu, A., Bastin, S., Masson, V., Drobinski, P.: Vertical structure of the urban boundary layer over Marseille under sea-breeze conditions, Bound.-Layer Meteorol., 118, 477-501, 2006.

Martano, P.: An algorithm for the calculation of the time dependent mixing height in coastal site, J. Appl. Meteorol., 41, 351-354, 2002.

Martucci, G., Matthey, C., Mitev, V., Richner, H.: Comparison between backscatter lidar and radiosonde measurements of the diurnal and nocturnal stratification in the lower troposphere, J. Atmos. Ocean. Technol., 24, 1231-1244, 2007.

Martucci, G., Milroy, C., and O'Dowd, C. D.: Detection of cloudbase height using Jenoptik CHM15K and Vaisala CL31 ceilometers, J. Atmos. Ocean. Technol., 2, 305-318, 2010.

Mastrantonio, G., Viola, A. P., Argentini, S., Fiocco, G., Giannini, L., Rossini, L., Abbate, G., Ocone, R., and Casonato, M.: Observations of sea breeze events in Rome and the surrounding area by a network of Doppler sodars, Bound.-Layer Meteorol., 71, 67-80, 1994.

Matthias, V. and Bösenberg, J.: Aerosol climatology for the planetary boundary layer derived from regular lidar measurements, Atmos. Res., 63, 221-245, 2002.

Matthias, V., Balis, D., Bösenberg, J., Eixmann, R., Iarlori, M., Komguem, L., Mattis, I., Papayannis, A., Pappalardo, G., Perrone, M. R., and Wang, X.: Vertical aerosol distribution over Europe: Statistical analysis of Raman lidar data from 10 European Aerosol Research Lidar Network (EARLINET) stations, J. Geophys. Res., 109, D18201, doi:10.1029/2004JD004638, 2004.

Menut, L., Flamant, C., Pelo, J., and Flamant, P. H.: Urban boundary-layer height determination from lidar measurements over Paris area, Appl. Opt., 38, 945-954, 1999.

Millán, M. M., Salvador, R., Mantilla, E., and Kallos, G.: Photooxidant dynamics in the Mediterranean basin in summer: results from European research projects, J. Geophys. Res., 102, 88118823, 1997.

Millan, M. M., Mantilla, E., Salvador, R., Carratalá, A., Sanz, M. J., Alonso, L., Gangoiti, G., and Navazo, M.: Ozone cycles in the western Mediterranean basin: interpretation of monitoring data in complex coastal terrain, J. Appl. Meteorol., 39, 487-508, 7383, 2000.

Milroy, C., Martucci, G., Lolli, S., Loaec, S., Sauvage, L., XuerefRemy, I., Lavrič, J. V., Ciais, P., and O’Dowd, C. D.: On the ability of pseudo-operational ground-based light detection and ranging (LIDAR) sensors to determine boundary-layer structure: intercomparison and comparison with in-situ radiosounding, Atmos. Meas. Tech. Discuss., 4, 563-597, doi:10.5194/amtd-4563-2011, 2011.

Monks, P., Granier, C., Fuzzi, S., Stohl, A., Williams, M. L., Akimoto, H., Amann, M., Baklanov, A., Baltensperger, U., Bey, I., Blake, N., Blake, R. S., Carslaw, K. S., Cooper, O. R., Dentener, F., Fowler, D., Fragkou, E., Frost, G. J., Generoso, S., Ginoux, P., Grewe, V., Guenther, A., Hansson, H. C., Henne, S., Hjorth, J., Hofzumahaus, A., Huntrieser, H., Isaksen, I. S.A., Jenkin, M. E., Kaiser, J., Kanakidou, M., Klimont, Z., Kulmala, M., Laj, 
P., Lawrence, M., Lee, J. D., Liousse, C., Maione, M., McFiggans, G., Metzger, A., Mieville, A., Moussiopoulos, N., Orlando, J. J., O’Dowd, C. D., Palmer, P. I., Parrish, D. D., Petzold, A., Platt, U., Pöschl, U., Prevot, A. S. H., Reeves, C. E., Reimann, S., Rudich, Y., Sellegri, K., Steinbrecher, R., Simpson, D., ten Brink, H., Theloke, J., van der Werf, G. R., Vautard, R., Vestreng, V., Vlachokostas, Ch., and von Glasow R.: Atmospheric composition change: global and regional air quality, Atmos. Environ., 43, 5268-5350, 2009.

Pandolfi, M., Cusack, M., Alastuey, A., and Querol, X.: Variability of aerosol optical properties in the Western Mediterranean Basin, Atmos. Chem. Phys., 11, 8189-8203, doi:10.5194/acp-11-81892011, 2011.

Pappalardo, G., Amodeo, A., Pandolfi, M., Wandinger, U., Ansmann, A., Bosenberg, J., Matthias, V., Amiridis, V., Tomasi, F. D., Frioud, M., Iarlori, M., Komguem, L., Papayannis, A., Rocadenbosch, F., and Wang, X.: Aerosol Lidar Intercomparison in the Framework of the EARLINET Project. 3. Raman Lidar Algorithm for Aerosol Extinction, Backscatter, and Lidar Ratio, Appl. Opt. 43, 5370-5385, 2004.

Pay, M. T., Jiménez-Guerrero, P., Jorba, O., Basart, S., Querol, X., Pandolfi, M., and Baldasano, J. M.: Spatio-temporal variability of concentrations and speciation of particulate matter across Spain in the CALIOPE modeling system, Atmos. Environ., 46, 376396, 2012.

Pérez, C., Sicard, M., Jorba, O., Comerón, A., and Baldasano J. M.: Summertime re-circulations of air pollutants over the northeastern Iberian coast observed from systematic EARLINET lidar measurements in Barcelona, Atmos. Environ., 38, 3983-4000, 2004.

Pey, J., Alastuey, A., Querol, X., and Rodríguez, S.: Monitoring of sources and atmospheric processes controlling air quality in an urban Mediterranean environment, Atmos. Environ., 44, 38, 4879-4890, 2010a.

Pey, J., Pérez, N., Querol, X., Alastuey, A., Cusack, M., Reche, C.: Intense winter atmospheric pollution episodes affecting the Western Mediterranean, Sci. Total Environ., 408, 1951-1959, 2010b.

Querol, X., A., Alastuey, T., Moreno, M. M., Viana, S., Castillo, J., Pey, S., Rodríguez, B., Artiñano, P., Salvador, M., Sánchez, S., Garcia Dos Santos, M. D., Herce Garraleta, R., FernandezPatier, S., Moreno-Grau, L., Negral, M. C., Minguillón, E., Monfort, M. J., Sanz, R., Palomo-Marín, E., Pinilla-Gil, Cuevas, E., de la Rosa, J., and Sánchez de la Campa, A.: Spatial and temporal variations in airborne particulate matter $\left(\mathrm{PM}_{10}\right.$ and $\left.\mathrm{PM}_{2.5}\right)$ across Spain 1999-2005, Atmos. Environ., 42, 3964-3979, 2008.
Reche, C., Viana, M., Moreno, T., Querol, X., Alastuey, A., Pey, J., Pandolfi, M., Prévôt, A., Mohr, C., Richard, A., Artiñano, B., Gomez-Moreno, F. J., and Cots N.: Peculiarities in atmospheric particle number and size-resolved speciation in an urban area in the western Mediterranean: Results from the DAURE campaign, Atmos. Environ., 45, 5282-5293, 2011.

Rodriguez, S., Querol, X., Alastuey, A., Kallos, G., and Kakaliagou O.: Saharan dust contributions to $\mathrm{PM}_{10}$ and TSP levels in Southern and Eastern Spain, Atmos. Environ., 35, 2433-2447, 2001.

Schuster, G. L., Dubovik, O., and Holben, B. N.: Ångström exponent and bimodal aerosol size distributions, J. Geophys. Res., 111, D07207, doi:101029/2005JD006328, 2006.

Sicard, M., Pérez, C., Rocadenbosch, F., Baldasano, J. M., and García-Vizcaino, D.: Mixed-layer depth determination in the Barcelona coastal area from regular lidar measurements: methods, results and limitations, Bound.-Lay. Meteorol., 119, 135157, 2006.

Sicard, M., Rocadenbosch, F., Reba, M. N. M., Comerón, A., Tomás, S., García-Vízcaino, D., Batet, O., Barrios, R., Kumar, D., and Baldasano, J. M.: Seasonal variability of aerosol optical properties observed by means of a Raman lidar at an EARLINET site over Northeastern Spain, Atmos. Chem. Phys., 11, 175-190, doi:10.5194/acp-11-175-2011, 2011.

Sicard, M., Mallet, M., García-Vizcaíno, D., Comerón, A., Rocadenbosch, F., Dubuisson P., and Muñoz-Porcar, C.: Intense dust and extremely fresh biomass burning outbreak in Barcelona, Spain: characterization of their optical properties and estimation of their direct radiative forcing, Environ. Res. Lett., 7, 034016, doi:10.1088/1748-9326/7/3/034016, 2012.

Stull, R. B.: Introduction to boundary layer meteorology, Kluwer Academic Publisher, Dordrecht, 670 pp., 1998.

Talbot, C., Augustin, P., Leroy, C., Willart, V., Delbarre, H., Khomenco, G.: Impact of a sea breeze on the boundary-layer dynamics and the atmospheric stratification in a coastal area of the North Sea, Bound.-Layer Meteorol., 125, 133-154, 2007.

Tsaknakis, G., Papayannis, A., Kokkalis, P., Amiridis, V., Kambezidis, H. D., Mamouri, R. E., Georgoussis, G., and Avdikos, G.: Inter-comparison of lidar and ceilometer retrievals for aerosol and Planetary Boundary Layer profiling over Athens, Greece, Atmos. Meas. Tech., 4, 1261-1273, doi:10.5194/amt-4-1261-2011, 2011. 